\title{
TRANSFERABLE RESISTANCE AND AMINOGLYCOSIDE-MODIFYING ENZYMES IN ENTEROCOCCI
}

\author{
H. Y. Chen* and J. D. Williams \\ Department of Medical Microbiology, The London Hospital Medical College, \\ London E1
}

\begin{abstract}
SUmmary. Ten isolates of Streptococcus faecalis and two isolates of $S$. faecium were studied together with an NCTC strain of each species. Antibiotic susceptibility tests showed different patterns of high-level resistance to aminoglycosides. Three $S$. faecalis strains were highly resistant to gentamicin and other aminoglycosides. By means of a filter membrane technique, transfer of high-level resistance to aminoglycosides was demonstrated from $S$. faecalis to $S$. faecalis, from $S$. faecium to $S$. faecalis and from $S$. faecalis to $S$. faecium, the last of which has not previously been described.

Aminoglycoside-modifying enzymes were assayed with radiolabelled cofactors. High-level resistance to gentamicin and other aminoglycosides could be attributed to the production of 2 "-O-phosphotransferases, 3'-O-phosphotransferases, 6-O-adenylyltransferases and $6^{\prime}-\mathrm{N}$-acetyltransferases. Other resistance mechanisms accounted for resistance in two strains of $S$. faecalis and one strain of $S$. faecium that were highly resistant only to streptomycin and one $S$. faecalis strain that was moderately resistant to all aminoglycosides. A low level of $6^{\prime}$-N-acetyltransferases was detected in the three strains of $S$. faecium but this did not confer high-level resistance to aminoglycosides and this trait could not be transferred.
\end{abstract}

\section{INTRODUCTION}

Synergy between penicillins and aminoglycosides against enterococci has been observed in vitro and in vivo (Hunter, 1947; Watanakunakorn, 1971; Sapico et al., 1972) and combination treatment has commonly been used in enterococcal infections (Moellering et al., 1971; Weinstein and Moellering, 1973). The emergence of enterococci with high-level resistance to aminoglycosides-minimum inhibitory concentration (MIC) $>1000 \mathrm{mg} / \mathrm{L}$ - has given rise to treatment problems because bactericidal synergy of penicillins and aminoglycosides cannot be achieved (Standiford et al., 1970; Watanakunakorn, 1971; Calderwood et al., 1977). Wild strains of Streptococcus faecalis with high-level resistance to gentamicin were first reported in

Received 15 Oct. 1984; accepted 2 Jan. 1985

* Permanent address: Clinical Research Laboratory of Antibiotics, Hua Shan Hospital, Shanghai First Medical College, China. 
France (Horodniceanu et al., 1979; Combes et al., 1983) and, more recently, in the USA, Thailand, Chile and England (Mederski-Samoraj and Murray, 1983; Murray et al., 1983; Birch et al., 1984). S. faecium strains highly resistant to gentamicin have not previously been reported.

In this paper we describe experiments to transfer aminoglycoside and other antibiotic resistance between enterococci and, in particular, to transfer high-level aminoglycoside resistance from $S$. faecalis to $S$. faecium. Aminoglycoside-modifying enzymes were also assayed in resistant enterococci and their transconjugants.

\section{Materials AND MethodS}

Bacterial strains. Ten isolates of $S$. faecalis and two isolates of $S$. faecium were studied and compared with NCTC reference strains. Two of the three $S$. faecalis strains with high-level resistance to gentamicin were received from Parma, Italy. The other isolates were collected from the London Hospital, London. The identities of all the test strains were confirmed by a series of biochemical tests (Cowan, 1974). The media used for culture were obtained from Oxoid.

Antibiotics and isotopes. The aminoglycoside-aminocyclitol antibiotics used were: streptomycin (Glaxo Laboratories Ltd, Greenford); neomycin (Biorex Lab Ltd, London); kanamycin (Winthrop Laboratories, Surrey); gentamicin (Roussel Laboratories, Wembley Park); netilmicin, 2'-N-ethyl-netilmicin and 6'-N-ethyl-netilmicin (Schering Corporation Bloomfield, USA); tobramycin (Eli Lilly and Co. Ltd, Basingstoke); spectinomycin (Upjohn Ltd, Sussex); rifampicin (Gruppo Lepetit SpA, Milan, Italy); and fucidin (Leo Laboratories Ltd, Bucks). Erythromycin, chloramphenicol and tetracycline were obtained from Sigma Chemical Co. Ltd, USA. The concentrations of the relevant antibiotics used for selecting resistance markers in the mating experiments were: rifampicin $256 \mathrm{mg} / \mathrm{L}$, gentamicin and kanamycin $512 \mathrm{mg} / \mathrm{L}$, erythromycin $4 \mathrm{mg} / \mathrm{L}$, chloramphenicol $32 \mathrm{mg} / \mathrm{L}$, tetracycline $4 \mathrm{mg} / \mathrm{L}$ and fucidin $25 \mathrm{mg} / \mathrm{L}$. Abbreviations of antibiotics and given in table III.

The radiolabelled cofactors $-\left(\mathrm{r}-{ }^{32} \mathrm{P}\right)$ ATP, $\left(8-{ }^{14} \mathrm{C}\right)$ ATP and $\left(1-{ }^{14} \mathrm{C}\right)$ acetyl coenzyme A -were purchased from Amersham International PLC, Bucks. Unlabelled cofactors were obtained from Sigma.

Sensitivity tests. Sensitivity tests with eight aminoglycoside-aminocyclitol and three other antibiotics were performed by the conventional plate dilution method with an inoculum of $10^{4}$ cfu on Isosensitest Agar (Oxoid). The MIC was taken as the lowest concentration at which no growth was seen after overnight incubation at $37^{\circ} \mathrm{C}$.

Mating experiments. S. faecalis strains G1, G2 and G3 and S. faecium strain 37 were used as donors. The rifampicin-resistant mutants (MIC $>500 \mathrm{mg} / \mathrm{L}$ ) of $S$. faecalis NCTC 775 and $S$. faecium NCTC 7171 were selected from agar plates containing increasing concentrations of rifampicin. These two strains and $S$. faecalis $\mathrm{JH} 2-2$, which were resistant to rifampicin and fucidin (Jacob and Hobbs, 1974), were used as recipients.

Donors and recipients were grown in Brain Heart Infusion Broth (BHI) and $0.2 \mathrm{ml}$ of a mixture of late-exponential-phase cultures of the donor and the recipient $(1: 4)$ was spread on to a filter membrane (type GS, $0.22 \mu \mathrm{m}, 47 \mathrm{~mm}$, Millipore Corp, Bedford, MA, USA) which was placed on BHI agar containing horse serum $5 \%$. The cells were washed off with $0.5 \mathrm{ml}$ of broth after incubation for $24 \mathrm{~h}$ at $37^{\circ} \mathrm{C}$ and $0.1-\mathrm{ml}$ volumes of appropriate dilutions of the cell suspension were spread on to the selective media incorporating rifampicin and another test antibiotic. The plates were incubated for $48 \mathrm{~h}$. The presumptive transconjugants were subcultured on the fucidin-containing agar for intraspecies transfers or on tellurite $0.04 \%$ and tetrazolium $0.01 \%$ agar for interspecies transfers and they were checked on the agar containing individual antibiotics or with antibiotic disks to observe the resistance markers carried over from the donor. The MICs of relevant antibiotics were then determined. Transfer frequencies were expressed as the number of the transconjugants per donor cell placed on the membrane.

Preparation of modifying enzyme extracts for aminoglycoside-antibiotics. Thirteen test strains, three recipients and three transconjugants were used for detection of enzymes. The organisms were subcultured into $10 \mathrm{ml}$ of BHI broth containing an appropriate aminoglycoside $(10 \mathrm{mg} / \mathrm{L})$ to which the strain was resistant. Of this overnight culture, $2 \mathrm{ml}$ was inoculated into 
$200 \mathrm{ml}$ of BHI broth to obtain heavy growth. Cells were harvested, washed with $10 \mathrm{~mm}$ Tris- $\mathrm{HCl}$

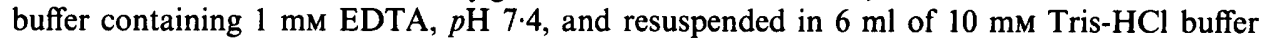
containing $10 \mathrm{mM} \mathrm{MgCl} 2$ and $10 \mathrm{~mm}$ dithiothreitol (DTT), $p \mathrm{H} \mathrm{7.8.} \mathrm{The} \mathrm{cell} \mathrm{suspension} \mathrm{was}$ disintegrated in a Mickle disintegrator (H. Mickle Laboratory Engineering Co., Surrey) for short intervals totalling $10 \mathrm{~min}$ at $4^{\circ} \mathrm{C}$ and most of the cells were broken. The supernate, which was separated from debris by centrifugation at $4000 \mathrm{~g}$ for $15 \mathrm{~min}$ at $4^{\circ} \mathrm{C}$, was then centrifuged at $100000 \mathrm{~g}$ for $2 \mathrm{~h}$. The supernate extracts were stored in small volumes at $-70^{\circ} \mathrm{C}$ until used.

Assay of modifying enzymes. The cellulose phosphate paper binding method was used to detect the modifying enzymes (Drasar, 1978; Shannon and Phillips, 1983).

For phosphotransferases (APH) and adenylyltransferases (AAD) the following mixtures were incubated for $45 \mathrm{~min}$ at $37^{\circ} \mathrm{C}: 25 \mu \mathrm{l}$ of $0.2 \mathrm{M}$ Tris- $\mathrm{HCl}$ buffer $(p \mathrm{H} 8 \cdot 1)$ containing $32 \mathrm{~mm}$ $\mathrm{MgCl}_{2}$ and $4 \mathrm{mM} \mathrm{DTT}, 25 \mu \mathrm{l}$ of a solution containing antibiotic 200,80 or $20 \mathrm{mg} / \mathrm{L}, 25 \mu \mathrm{l} \mathrm{of} 1 \mathrm{~mm}$ (r- $\left.{ }^{32} \mathrm{P}\right)$ ATP for APH (specific activity $\left.12.5 \mathrm{Ci} / \mathrm{mol}\right)$ or $0.4 \mathrm{~mm}\left(8-{ }^{14} \mathrm{C}\right)$ ATP for AAD $(5 \mathrm{Ci} / \mathrm{mol})$, and $25 \mu$ l of enzyme extract.

For acetyltransferases (AAC) the following mixture was incubated for $30 \mathrm{~min}$ at $37^{\circ} \mathrm{C}: 25 \mu \mathrm{l}$ of $0.12 \mathrm{M}$ citrate buffer $\left(p \mathrm{H} \mathrm{5.7)}\right.$ containing $12 \mathrm{mM} \mathrm{MgCl}{ }_{2}$ and $4 \mathrm{mM}$ DTT, $20 \mu \mathrm{l}$ of a solution containing antibiotic 200,80 or $20 \mathrm{mg} / \mathrm{L}, 10 \mu \mathrm{l}$ of $0.3 \mathrm{~mm}\left(1-{ }^{14} \mathrm{C}\right)$ acetyl coenzyme $\mathrm{A}(10 \mathrm{Ci} / \mathrm{mol})$, and $25 \mu \mathrm{l}$ of enzyme extract.

The selected antibiotics used as substrates were: gentamicin, neomycin and streptomycin for phosphorylation; gentamicin for adenylylation; kanamycin, amikacin, netilmicin, 2'-N-ethylnetilmicin ( $\left.2^{\prime}-\mathrm{Net}\right)$ and $6^{\prime}-\mathrm{N}$-ethyl-netilmicin $\left(6^{\prime}-\mathrm{Net}\right)$ for acetylation, in order to infer the sites of modification (Reynolds and Smith, 1979; Shannon and Phillips, 1983; tables I and II). Gentamicin and neomycin were also used to observe acetylation by enzyme extracts.

The reaction mixture $(70 \mu \mathrm{l})$ was transferred to the cellulose phosphate paper $(2 \times 2 \mathrm{~cm})$.

TABLE I

Specificity of modifying enzymes inferred from their reactions with various aminoglycoside-aminocyclitol antibiotics

\begin{tabular}{|c|c|c|}
\hline Reaction & Antibiotic & Inferred specificity \\
\hline Phosphorylation & $\begin{array}{l}\text { Gentamicin } \\
\text { Neomycin } \\
\text { Streptomycin }\end{array}$ & $\begin{array}{l}\text { APH }\left(2^{\prime \prime}\right) \\
\text { APH(3') } \\
\text { APH(6) or APH(3') }\end{array}$ \\
\hline Adenylylation & $\begin{array}{l}\text { Gentamicin } \\
\text { Neomycin } \\
\text { Streptomycin } \\
\text { Spectinomycin }\end{array}$ & $\begin{array}{l}\operatorname{AAD}\left(2^{\prime \prime}\right) \\
\operatorname{AAD}\left(4^{\prime}\right)\left(4^{\prime \prime}\right) \\
\operatorname{AAD}(6) \text { or } \operatorname{AAD}\left(3^{\prime \prime}\right)(9) \\
\operatorname{AAD}(9) \text { or } \operatorname{AAD}\left(3^{\prime \prime}\right)(9)\end{array}$ \\
\hline Acetylation & $\begin{array}{l}\text { Gentamicin } \\
\text { Neomycin } \\
\text { Kanamycin } \\
\text { Amikacin } \\
\text { Netilmicin } \\
\text { 2'-N-ethyl-netilmicin }^{\prime} \text { '-N-ethyl-netilmicin }\end{array}$ & $\begin{array}{l}\text { AAC } \\
\text { AAC } \\
\text { AAC }(3) \text { or AAC }\left(6^{\prime}\right) \\
\text { presumable AAC }\left(6^{\prime}\right) \\
\text { See table II }\end{array}$ \\
\hline
\end{tabular}

TABLE II

Site specificity of acetyltransferases in S. faecium as determined by reactions with netilmicin and its derivatives

\begin{tabular}{cccc}
\hline & \multicolumn{2}{c}{ Acetylation of } & $\begin{array}{c}\text { Inferred } \\
\text { acetylation } \\
\text { site }\end{array}$ \\
\cline { 1 - 4 } Netilmicin & $2^{\prime}$-N-ethyl-netilmicin & $6^{\prime}$-N-ethyl-netilmicin & \\
\hline+ & + & + & 3 \\
+ & + & + & $2^{\prime}$ \\
+ & + & - & $6^{\prime}$ \\
\hline
\end{tabular}




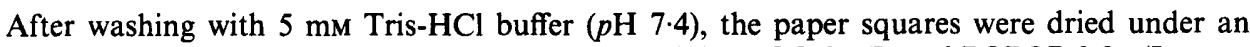
infrared lamp and soaked in $5 \mathrm{ml}$ of toluene containing PPO $3 \mathrm{~g} / \mathrm{L}$ and POPOP $0.3 \mathrm{~g} / \mathrm{L}$.

When APH was detected the cellulose phosphate paper was pre-soaked with $20 \mathrm{mM}$ ATP in a saturated solution of sodium pyrophosphate and dried to reduce the non-specific binding of ATP (Drasar, 1978).

Radioactivity on paper was counted in a liquid scintillation spectrometer (SL30 Intertechnique Ltd, Middlesex). Counts which were at least twice those of the controls without antibiotics, were regarded as positive. The sites of modification were inferred from substrate profiles and from their chemical structures.

\section{RESULTS}

\section{Susceptibility to antibiotics}

The antibiotic susceptibility of the test strains in comparison with the reference strains is shown in table III. $S$. faecalis NCTC 775, $S$. faecium NCTC 7171, their rifampicin-resistant mutants and $S$. faecalis $\mathrm{JH} 2-2$ possessed low-level resistance to aminoglycosides (MIC $\leqslant 512 \mathrm{mg} / \mathrm{L}$ ). Three isolates of $S$. faecalis were highly resistant to gentamicin but had different antibiograms. $S$. faecalis $\mathrm{Gl}$ had low-level resistance to streptomycin and neomycin. S. faecalis strains G2 and G3 were highly resistant (MIC $\geqslant 1024 \mathrm{mg} / \mathrm{L}$ ) to all the test aminoglycosides except that the MIC of netilmicin was 512 $\mathrm{mg} / \mathrm{L}$ for $S$. faecalis $\mathrm{G} 3$. Three different resistance patterns were observed in the other enterococci which were not highly resistant to gentamicin. $S$. faecalis strains 4, 45, 55 and 56 and $S$. faecium 37 were highly resistant to streptomycin, neomycin and kanamycin. $S$. faecalis strains 10 and 11 and $S$. faecium 44 were highly resistant only to streptomycin. $S$. faecalis 14 was moderately resistant to all the aminoglycosides with high-level resistance to neomycin and amikacin. Nine out of ten $S$. faecalis strains

TABLE III

Susceptibility of enterococci to antibiotics

\begin{tabular}{|c|c|c|c|c|c|c|c|c|c|c|c|c|}
\hline \multirow[b]{2}{*}{ Strain } & & \multicolumn{11}{|c|}{$\mathrm{MIC}(\mathrm{mg} / \mathrm{L})$ against the given strain of } \\
\hline & & Sm & Neo & Kan & Gen & Net & Tob & Ami & Spe & Ery & $\mathrm{Cm}$ & Tc \\
\hline S. faecalis & $\begin{array}{r}\text { G1 } \\
\text { G2 } \\
\text { G3 } \\
4 \\
45 \\
55 \\
56 \\
10 \\
11 \\
14 \\
\text { NCTC } 775\end{array}$ & $\begin{array}{r}128 \\
>2048 \\
>2048 \\
>2048 \\
>2048 \\
>2048 \\
>2048 \\
>2048 \\
>2048 \\
256 \\
128\end{array}$ & $\begin{array}{r}256 \\
>2048 \\
>\mathbf{2 0 4 8} \\
>\mathbf{2 0 4 8} \\
>\mathbf{2 0 4 8} \\
>\mathbf{2 0 4 8} \\
>\mathbf{2 0 4 8} \\
256 \\
256 \\
2048 \\
64\end{array}$ & $\begin{array}{r}>2048 \\
>2048 \\
>2048 \\
>2048 \\
>2048 \\
>\mathbf{2 0 4 8} \\
>2048 \\
64 \\
64 \\
256 \\
64\end{array}$ & $\begin{array}{r}>\mathbf{2 0 4 8} \\
>\mathbf{2 0 4 8} \\
>\mathbf{2 0 4 8} \\
16 \\
16 \\
16 \\
16 \\
16 \\
16 \\
32 \\
8\end{array}$ & $\begin{array}{r}>2048 \\
>2048 \\
512 \\
8 \\
8 \\
8 \\
8 \\
16 \\
8 \\
16 \\
8\end{array}$ & $\begin{array}{r}>\mathbf{2 0 4 8} \\
>\mathbf{2 0 4 8} \\
>\mathbf{2 0 4 8} \\
32 \\
16 \\
32 \\
32 \\
64 \\
64 \\
64 \\
16\end{array}$ & $\begin{array}{r}>\mathbf{2 0 4 8} \\
>\mathbf{2 0 4 8} \\
\mathbf{1 0 2 4} \\
512 \\
128 \\
256 \\
512 \\
256 \\
256 \\
1024 \\
128\end{array}$ & $\begin{array}{r}64 \\
64 \\
64 \\
64 \\
64 \\
128 \\
64 \\
64 \\
64 \\
64 \\
64 \\
64 \\
64\end{array}$ & $\begin{array}{r}1 \\
\leqslant 0 \cdot 25 \\
0 \cdot 5 \\
>128 \\
>128 \\
>128 \\
>128 \\
1 \\
1 \\
\leqslant 0.25 \\
1\end{array}$ & $\begin{array}{r}128 \\
8 \\
128 \\
64 \\
64 \\
64 \\
64 \\
8 \\
8 \\
8 \\
4\end{array}$ & $\begin{array}{r}16 \\
64 \\
64 \\
128 \\
>128 \\
64 \\
128 \\
128 \\
128 \\
1 \\
1\end{array}$ \\
\hline S. faecium & $\begin{array}{r}\text { NCTC } 7171 \\
37 \\
44\end{array}$ & $\begin{array}{r}32 \\
>2048 \\
>2048\end{array}$ & $\begin{array}{r}16 \\
>2048 \\
16\end{array}$ & $\begin{array}{r}256 \\
>2048 \\
128\end{array}$ & $\begin{array}{l}4 \\
8 \\
8\end{array}$ & $\begin{array}{r}64 \\
128 \\
128\end{array}$ & $\begin{array}{l}128 \\
256 \\
128\end{array}$ & $\begin{array}{r}64 \\
128 \\
64\end{array}$ & $\begin{array}{l}64 \\
64 \\
32\end{array}$ & $\begin{array}{r}2 \\
>128 \\
>128\end{array}$ & $\begin{array}{r}8 \\
32 \\
8\end{array}$ & $\begin{array}{r}0.5 \\
128 \\
64\end{array}$ \\
\hline $\begin{array}{l}\text { S. faecalis } \\
\text { S. faecalis } \\
\text { S. faecium }\end{array}$ & $\begin{array}{r}\mathrm{JH} 2-2 \\
775 \mathrm{R} \\
7171 \mathrm{R}\end{array}$ & $\begin{array}{r}128 \\
128 \\
32\end{array}$ & $\begin{array}{r}256 \\
128 \\
16\end{array}$ & $\begin{array}{r}256 \\
64 \\
128\end{array}$ & $\begin{array}{r}16 \\
8 \\
4\end{array}$ & $\begin{array}{r}16 \\
8 \\
64\end{array}$ & $\begin{array}{l}32 \\
16 \\
64\end{array}$ & $\begin{array}{r}512 \\
128 \\
64\end{array}$ & $\begin{array}{l}32 \\
64 \\
64\end{array}$ & $\begin{array}{r}0.5 \\
1 \\
4\end{array}$ & $\begin{array}{l}4 \\
4 \\
4\end{array}$ & $\begin{array}{r}1 \\
1 \\
0.5\end{array}$ \\
\hline
\end{tabular}

Figures in bold type indicate high-level resistance to antibiotics.

Sm, Streptomycin; Neo, neomycin; Kan, kanamycin; Gen, gentamicin; Net, netilmicin; Tob, tobramycin; Ami, amikacin; Spe, spectinomycin; Ery, Erythromycin; $\mathrm{Cm}$, chloramphenicol; Tc, tetracycline. 
carried tetracycline resistance markers. Three strains of $S$. faecium were slightly more resistant to netilmicin and tobramycin than the $S$. faecalis NCTC 775 .

All the enterococci tested were of similar susceptibility to spectinomycin (MIC $90 \mathrm{c}$. $64 \mathrm{mg} / \mathrm{L})$.

\section{Transfer of resistance}

The results of mating experiments are shown in table IV. Selected resistance was transferred from $S$. faecalis strains G1, G2 and G3 to $S$. faecalis $\mathrm{JH} 2-2$, from $S$. faecium 37 to $S$. faecalis $775 \mathrm{R}$ and from $S$. faecalis $\mathrm{G} 3$ to $S$. faecium $7171 \mathrm{R}$ with other resistance markers. The transfer frequencies varied with different donors and recipients. All the resistance markers to aminoglycosides were transferred from $S$. faecalis G3 to $S$. faecium $7171 \mathrm{R}$ but not the resistance to chloramphenicol and tetracycline.

\section{Detection of modifying enzymes}

The aminoglycoside-modifying enzymes detected in enterococci and their transconjugants are shown in table $\mathrm{V}$. There were no appreciable modifying-enzyme activities in $S$. faecalis strains $775 \mathrm{R}, \mathrm{JH} 2-2,10,11$ and 14 . High activities of two distinct phosphotransferases $\mathrm{APH}\left(2^{\prime \prime}\right)$ and $\mathrm{APH}\left(3^{\prime}\right)$, which modified gentamicin and neomycin respectively, were detected in three highly gentamicin-resistant $S$. faecalis strains. APH( $\left.3^{\prime}\right)$ was found in $S$. faecalis strains 4, 45, 55 and 56 and $S$. faecium 37 and a low activity of APH $\left(2^{\prime \prime}\right)$ was also found in $S$. faecalis 56 and S. faecium 37 . Streptomycin-modifying adenylyltransferases were found in these five strains but not in $S$. faecalis strains 10 and 11 and $S$. faecium 44 . The adenylyltransferases failed to modify gentamicin, neomycin and spectinomycin.

The three highly gentamicin-resistant $S$. faecalis strains produced acetyltransferases which could modify gentamicin, kanamycin, amikacin, neomycin and netilmicin, but the latter two compounds seemed to be poor substrates for enzymes from $S$. faecalis $\mathrm{G} 2$. All the three $S$. faecium strains were acetyltransferase-producers which could acetylate netilmicin and 2'-Net but not 6'-Net (table II).

Enzyme activity was also assayed in the three recipients and three transconjugants (table V). The low-level AAC $\left(6^{\prime}\right)$ was not affected by the acquisition of rifampicin resistance in $S$. faecium $7171 \mathrm{R}$. All the traits of aminoglycoside-modifying enzymes were transferred from the three donors to the corresponding transconjugants except for the $\mathrm{AAC}\left(6^{\prime}\right)$ in $S$. faecium 37.

\section{Discussion}

All the test isolates were generally resistant to aminoglycoside-aminocyclitol antibiotics and most MICs were above clinically attainable serum levels. The isolates with low-level MICs were susceptible to the combinations of penicillins and aminoglycosides but bactericidal synergy between penicillins and aminoglycosides could not be obtained for strains with high-level MICs of aminoglycosides $(\leqslant 1024$ mg/L) (Standiford et al., 1970; Zimmermann et al., 1971; Krogstad et al., 1978a and b). Because combinations of penicillins and gentamicin are widely used and highly gentamicin-resistant $S$. faecalis strains have emerged, the determination of susceptibility to aminoglycosides, especially gentamicin is of clinical importance in predicting the results of treatment of enterococcal infections with combinations of these antibiotics. 


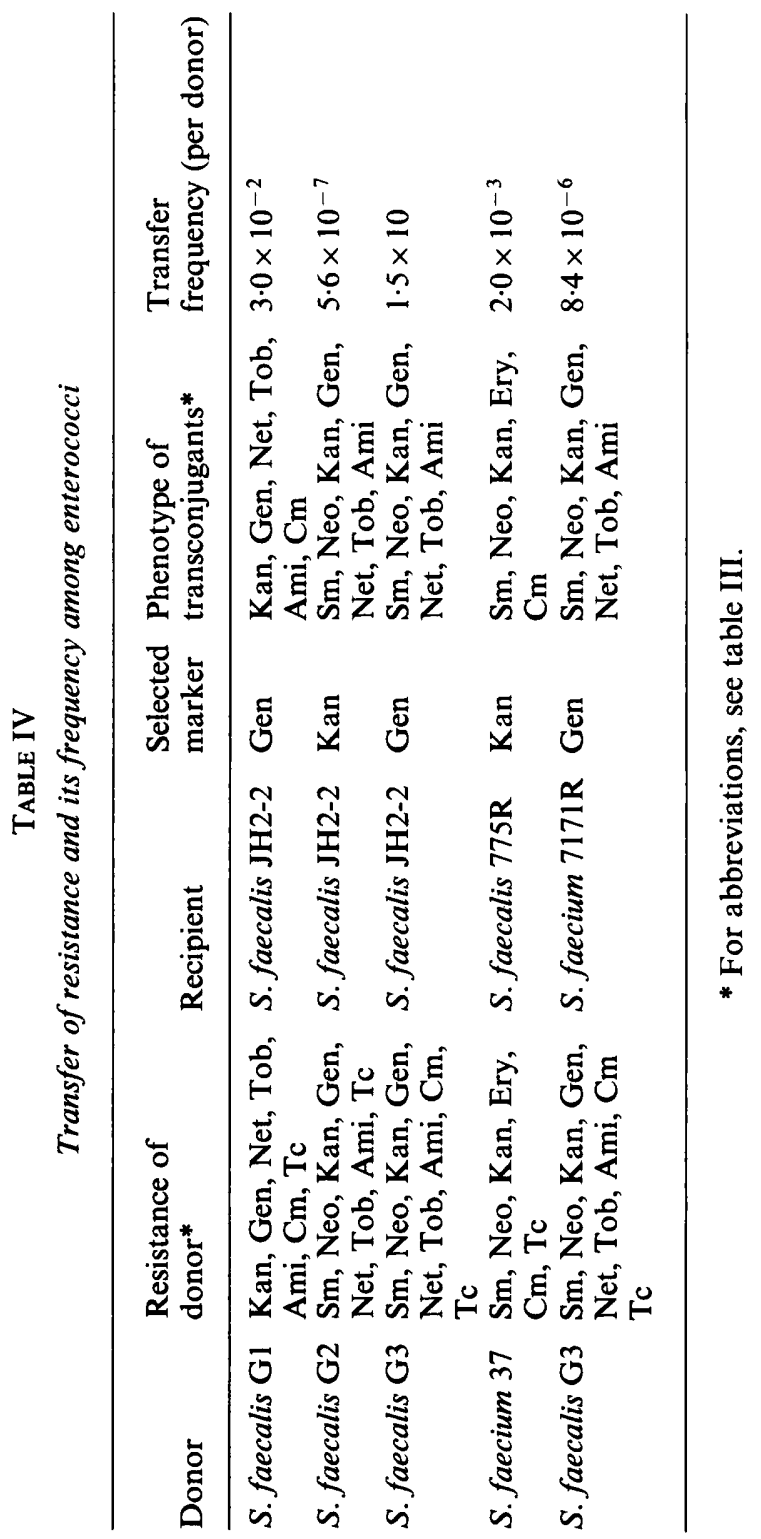


TABLE V

Presence of aminoglycoside-modifying enzymes in enterococci and their transconjugants

\begin{tabular}{|c|c|c|c|c|}
\hline \multirow[b]{2}{*}{ Strains } & & \multicolumn{3}{|c|}{ Modification sites for } \\
\hline & & APH & $\mathrm{AAD}$ & AAC \\
\hline S. faecalis & $\begin{array}{l}\text { G1 Donor } \\
\text { G2 Donor } \\
\text { G3 Donor } \\
4 \\
45 \\
55 \\
56 \\
10 \\
11 \\
14 \\
775 R \text { Recipient } \\
\text { JH2-2 Recipient }\end{array}$ & $\begin{array}{c}2^{\prime \prime}, 3^{\prime} \\
2^{\prime \prime}, \\
2^{\prime \prime}, 3^{\prime} \\
3^{\prime} \\
3^{\prime} \\
3^{\prime} \\
3^{\prime \prime}, 3^{\prime} \\
\ldots \\
\ldots \\
\ldots \\
\ldots\end{array}$ & $\begin{array}{l}\overline{6} \\
6 \\
6 \\
6 \\
6 \\
6 \\
\cdots \\
\cdots \\
\cdots \\
\cdots \\
\cdots\end{array}$ & $\begin{array}{l}6^{\prime *} \\
6^{\prime *} \\
6^{\prime *} \\
\cdots \\
\cdots \\
\ldots \\
6 \ldots \\
\cdots \\
\cdots \\
\cdots \\
\cdots\end{array}$ \\
\hline S. faecium & $\begin{array}{l}37 \\
44 \\
\text { NCTC } 7171 \\
7171 \text { R Recipient }\end{array}$ & $\begin{array}{c}2^{\prime \prime}, 3^{\prime} \\
\ldots \\
\ldots \\
\ldots\end{array}$ & $\begin{array}{l}6 \\
\ldots \\
\cdots \\
\ldots\end{array}$ & $\begin{array}{l}6^{\prime} \dagger \\
6^{\prime} \dagger \\
6^{\prime} \dagger \\
6^{\prime} \dagger\end{array}$ \\
\hline $\begin{array}{l}\text { Transconjugants } \\
\text { S. faecalis } \\
\text { S. faecalis } \\
\text { S. faecium }\end{array}$ & $\begin{array}{l}\text { G1XJH } \\
\text { 37X775R } \\
\text { G3X7171R }\end{array}$ & $\begin{array}{l}2^{\prime \prime}, 3^{\prime} \\
2^{\prime \prime}, 3^{\prime} \\
2^{\prime \prime}, 3^{\prime}\end{array}$ & $\begin{array}{l}\dddot{6} \\
6\end{array}$ & $\begin{array}{l}6^{*} \\
\dddot{6^{*}}, 6^{\prime} \dagger\end{array}$ \\
\hline
\end{tabular}

* Amikacin-modifying subgroup of $\mathrm{AAC}\left(6^{\prime}\right)$;

$\dagger$ a different subgroup of AAC (6');

$\ddagger$ names of transconjugants are expressed as working numbers of donor $\times$ recipient

High-level resistance to aminoglycosides in enterococci was attributed mainly to the production of aminoglycoside-modifying enzymes although defective uptake of the aminoglycoside has been reported (Moellering et al., 1980) and some high-level resistance to streptomycin was ribosomal (Zimmermann et al., 1971). Elipoulos et al. (1984) studied the mechanism of high-level resistance to streptomycin in 12 isolates of $S$. faecalis resistant only to streptomycin. Six were streptomycin-adenylyltransferase producers. Three enzyme-negative strains tested showed ribosomal resistance.

In our study, streptomycin-modifying enzymes could not be detected in $S$. faecalis strains 10 and 11 and $S$. faecium 44 which were highly resistant only to streptomycin and this resistance was presumably ribosomal. It was still not certain whether the ribosomal resistance co-existed with the enzymatic resistance in the enzyme-producing strains.

The sites of the modifications could be inferred from the selected substrates (tables I and II). Phosphotransferases were detected in the three gentamicin-resistant $S$. faecalis strains and other neomycin- and kanamycin-resistant strains. The presence of $\mathrm{APH}\left(2^{\prime \prime}\right)$ was inferred from the modification of gentamicin (gentamicin C) which possesses a $2^{\prime \prime}-\mathrm{OH}$ group but no other target sites for known phosphotransferases. For the same reason, APH $\left(3^{\prime}\right)$ was inferred from the modification of neomycin (neomycin B and C) (Davies and Smith, 1978; Courvalin et al., 1980; Shannon and Phillips, 1983). Because gentamicin lacks a $3^{\prime}-\mathrm{OH}$ group and neomycin lacks a $2^{\prime \prime}-\mathrm{OH}$ group, modifications of both antibiotics indicated the possibility of co-existence of two distinct enzymes. Adenylyltransferases for streptomycin were found but no enzyme activity could be detected when spectinomycin, gentamicin or neomycin were used as 
substrates. Therefore, these enzymes were presumably AAD (6) (Davies and Smith, 1978; Shannon and Phillips, 1983). Acetyltransferases which acetylated gentamicin, kanamycin and amikacin were found in the three gentamicin resistant $S$. faecalis strains. Amikacin does not possess an amino group at the $2^{\prime}$ position and is not attacked by the AAC(3) described so far; therefore the $6^{\prime}-\mathrm{NH}_{2}$ group was likely to be the target site for acetylation.

The enzyme from $S$. faecalis $\mathrm{G} 2$ could not acetylate netilmicin and neomycin as efficiently as that from $S$. faecalis strains G1 and G3 (data not shown). Its enzymatic activity may have been insufficient for these two compounds or the enzyme may have belonged to a different subgroup.

Although the MICs of aminoglycosides for the three $S$. faecium strains were different, similar enzymes which acetylated gentamicin, neomycin, netilmicin and $2^{\prime}$-Net but not $6^{\prime}$-Net or amikacin, were found. They were likely to be in a subgroup of AAC $\left(6^{\prime}\right)$ different from that found in $S$. faecalis. The genes coding for this $\mathrm{AAC}\left(6^{\prime}\right)$ could not be transferred from $S$. faecium 37 to $S$. faecalis $775 R$ like those coding $\operatorname{APH}\left(2^{\prime \prime}\right), \operatorname{APH}\left(3^{\prime}\right)$ and $\operatorname{AAD}(6)$. This finding was consistent with the report that AAC $\left(6^{\prime}\right)$ in $S$. faecium could not be transferred nor the phenotypic resistance cured (Wennersten and Moellering, 1980). The genes appeared to be located on the chromosome. Although this $\mathrm{AAC}\left(6^{\prime}\right)$ had low-level activity against gentamicin, the MICs for $S$. faecium remained 4-8 $\mathrm{mg} / \mathrm{L}$. The MICs of netilmicin and tobramycin for $S$. faecium are higher than those for $S$. faecalis with low level resistance (Moellering et al., 1979), and $\mathrm{AAC}\left(6^{\prime}\right)$ might account for the difference.

Low-level activity of phosphotransferases against gentamicin was found in $S$. faecalis 56, S. faecium 37 and its transconjugant $S$. faecalis $37 \times 775 \mathrm{R}$ which acquired this characteristic from $S$. faecium 37 . These strains were still relatively susceptible to gentamicin. In $S$. faecalis $\mathrm{G} 1$, there were $\mathrm{APH}\left(3^{\prime}\right)$ and $\mathrm{AAC}\left(6^{\prime}\right)$ which modified neomycin but they did not confer high-level neomycin resistance to the strain. Indeed, some modified aminoglycosides retain substantial antibiotic activities. Moreover, susceptibility also depends on the balance between the rate of uptake and the rate of inactivation of the aminoglycosides (Brayan and Van Den Elzen, 1977).

Three concentrations of substrate antibiotics were used in the enzyme assay. In phosphorylation and acetylation experiments, the scintillation counts were in direct proportion to the substrate concentrations. Enzyme activity fell to low levels when the concentrations of substrates fell to $20 \mathrm{mg} / \mathrm{L}$. Higher concentrations of substrate antibiotics led to increased phosphorylation and acetylaction. In most adenylylation experiments, activity appeared to be in inverse proportion to concentrations when streptomycin was used as substrate. Supplementary experiments on the relationship between streptomycin concentration and scintillation counts showed that the adenylylation was inhibited by increased concentrations of streptomycin. The optimum concentration of streptomycin for adenylylation in these laboratory conditions was 20 $\mathrm{mg} / \mathrm{L}$.

No enzymes were found in $S$. faecalis 14 which was less susceptible to all the aminoglycosides. It was presumed that the resistance was due to other mechanisms such as the cell wall barrier, defective uptake or ribosomal resistance.

Transfer of resistance in enterococci is mediated by plasmids which are not always detectable (Jacob and Hobbs, 1974; Horodniceanu et al., 1979; Le Bouguenec and Horodniceanu, 1982). Buu-Hoi et al (1984) reported the transfer of resistance to 
macrolides, lincosamides and streptogramin B from $S$. faecalis to $S$. faecium. In the present study, resistance to aminoglycosides was transferred from $S$. faecalis G3 to $S$. faecium $7171 \mathrm{R}$. S. faecium $7171 \mathrm{R}$ presumably acquired the genes coding for $\mathrm{APH}\left(2^{\prime \prime}\right)$, $\operatorname{APH}\left(3^{\prime}\right), \operatorname{AAD}(6)$ and $\mathrm{AAC}\left(6^{\prime}\right)$ from the donor despite the pre-existence in it of a low-level of $\mathrm{AAC}\left(6^{\prime}\right)$. The expression of the acquired $\mathrm{AAC}\left(6^{\prime}\right)$ which modified amikacin, obscured the original $\mathrm{AAC}\left(6^{\prime}\right)$ which did not modify amikacin. In this case, it was difficult to detect the production of the underlying enzymes by their substrate profiles. This $S$. faecium transconjugant with high resistance to gentamicin suggests that resistant strains of $S$. faecium may emerge in the future.

Infections caused by the multiresistant enterococci can be very refractory because synergy can not be obtained by the combination of penicillins and aminoglycosides. The three $S$. faecalis strains and the transconjugants with high resistance to gentamicin were not resistant to all the antibiotics. For instance, $S$. faecalis $G 1$ did not produce streptomycin-modifying enzymes and had only low-level resistance to streptomycin, $S$. faecalis $\mathbf{G} 2$ was sensitive and $S$. faecalis $\mathrm{G} 3$ was moderately susceptible to erythromycin. The transconjugant, $S$. faecium $\mathrm{G} 3 \times 7171 \mathrm{R}$, was slightly susceptible to tetracycline. Sensitivity tests with a wider range of antibiotics and more combination tests may be useful. Adenylyltransferases for spectinomycin were not found and the majority of the test strains were inhibited by spectinomycin $64 \mathrm{mg} / \mathrm{L}$. However, antagonism between penicillin $G$ and spectinomycin has been reported in two $S$. faecalis strains including JH2-2 (Combes et al., 1983). Because synergy between penicillins and gentamicin cannot be achieved with enterococci highly resistant to gentamicin, the use of other aminoglycosides resistant to modifying enzymes should be explored.

The research was partly supported by ORS Award No. 83968, UK, and we also thank Schering Corporation, Bloomfield, New Jersey, USA for netilmicin derivatives.

\section{REFERENCES}

Birch B R, Keaney M G L, Ganguli L A 1984 Antibiotic susceptibility and biochemical properties of Streptococcus faecalis strains reacting with both D and G antisera. Journal of Clinical Pathology 37:1289-1292.

Brayan L E, Van Den Elzen H M 1977 Effects of membrane-energy mutations and cations on streptomycin and gentamicin accumulation by bacteria: a model for entry of streptomycin and gentamicin in susceptible and resistant bacteria. Antimicrobial Agents and Chemotherapy 12:163-177.

Buu-Hoi A, Bieth G, Horaud T 1984 Broad host range of streptococcal macrolide resistance plasmids. Antimicrobial Agents and Chemotherapy 25:289-291.

Calderwood S A, Wennersten C, Moellering R C, Kunz L J, Krogstad D J 1977 Resistance to six aminoglycosidic aminocyclitol antibiotics among enterococci: Prevalence, evolution and relationship to synergism with penicillin. Antimicrobial Agents and Chemotherapy 12:401-405.

Combes T, Carlier C, Courvalin P 1983 Aminoglycoside-modifying enzyme content of a multiply resistant strain of Streptococcus faecalis. Journal of Antimicrobial Chemotherapy 11:41-47.

Courvalin P, Carlier C, Collatz E 1980 Plasmid-mediated resistance to aminocyclitol antibiotics in Group D Streptococci. Journal of Bacteriology 143:541-551.

Cowan S T 1974 Cowan and Steel's Manual for the identification of medical bacteria, 2nd edn. Cambridge University Press, Cambridge, pp 51-55.

Davies J, Smith D I 1978 Plasmid-determined resistance to antimicrobial agents. Annual Review of Microbiology 32:468-518. 
Drasar F A 1978 Detection of aminoglycoside degrading enzymes. In: Reeves D S, Phillips I, Williams $\mathbf{J} \mathbf{D}$, Wise $\mathbf{R}$ (eds) Laboratory methods in antimicrobial chemotherapy. Churchill-Livingstone, Edinburgh, pp 70-75.

Eliopoulos G M, Farber B F, Murray B E, Wennersten C, Moellering R C 1984 Ribosomal resistance of clinical enterococcal isolates to streptomycin. Antimicrobial Agents and Chemotherapy 25:398-399.

Horodniceanu T, Bougueleret L, El-Solh N, Bieth G, Delbos F 1979 High-level, plasmid-borne resistance to gentamicin in Streptococcus faecalis subsp. zymogenes. Antimicrobial Agents and Chemotherapy 16:686-689.

Hunter T H 1947 Use of streptomycin in the treatment of bacterial endocarditis. American Journal of Medicine 2:436-442.

Jacob A E, Hobbs S J 1974 Conjugal transfer of plasmid-borne multiple antibiotic resistance in Streptococcus faecalis var. zymogenes. Journal of Bacteriology 117:360-372.

Krogstad D J, Korfhagen T R, Moellering R C, Wennersten C, Swartz M N 1978a Plasmid-mediated resistance to antibiotic synergism in enterococci. Journal of Clinical Investigation 61:1645-1654.

Krogstad D J et al 1978b Aminoglycoside-inactivating enzymes in clinical isolates of Streptococcus faecalis. An explanation for resistance to antibiotic synergism. Journal of Clinical Investigation 62:480-486.

Le Bouguenec C, Horodniceanu T 1982 Conjugative R plasmids in Streptococcus faecium (Group D). Antimicrobial Agents and Chemotherapy 21:698-705.

Mederski-Samoraj B D, Murray B E 1983 High-level resistance to gentamicin in clinical isolates of enterococci. Journal of Infectious Diseases 147:751-757.

Moellering R C, Korzeniowski O M, Sande M A, Wennersten C B 1979 Species-specific resistance to antimicrobial synergism in Streptococcus faecium and Streptococcus faecalis. Journal of Infectious Diseases 140:203-208.

Moellering R C, Murray B E, Schoenbaum S C, Adler J, Wennersten C B 1980 A novel mechanism of resistance to penicillin-gentamicin synergism in Streptococcus faecalis. Journal of Infectious Diseases 141:81-86.

Moellering R C, Wennersten C, Weinberg A N 1971 Synergy of penicillin and gentamicin against enterococci. Journal of Infectious Diseases 124 (Suppl): S207-209.

Murray B E , Tsao J, Panida J 1983 Enterococci from Bangkok, Thailand, with high-level resistance to currently available aminoglycosides. Antimicrobial Agents and Chemotherapy 23:799-802.

Reynolds A V, Smith J T 1979 Enzymes which modify aminoglycoside antibiotics. In: Reeves D, Geddes A. (eds) Recent advances in infection, vol 1. Churchill-Livingstone, Edinburgh, pp 165-181.

Sapico F L, Keys T F, Hewitt W L 1972 Experimental enterococcal endocarditis II. Study of in vivo syngergism of penicillin and streptomycin. American Journal of Medical Sciences 263:128-135.

Shannon K P, Phillips I 1983 Detection of aminoglycoside-modifying strains of bacteria. In: Russell A D, Quesnel L B (eds) Antibiotics: assessment of antimicrobial activity and resistance. Academic Press, London, pp 183-198.

Standiford H D, de Maine J B, Kirby W M M 1970 Antibiotic synergism of enterococci. Relation to inhibitory concentrations. Archives of Internal Medicine 126:255-259.

Watanakunakorn C 1971 Penicillin combined with gentamicin or streptomycin: synergism against enterococci. Journal of Infectious Diseases 124:581-586.

Weinstein A J, Moellering R C 1973 Penicillin and gentamicin therapy for enterococcal infections. Journal of American Medical Association 223:1030-1032.

Wennersten C B, Moellering R C 1980 Mechanism of resistance to penicillin-aminoglycoside synergism in Streptococcus faecium. In: Nelson J D, Grassi C (eds) Current chemotherapy and infectious diseases, vol 1. American Society for Microbiology, Washington D.C. pp 710-712.

Zimmermann R A, Moellering R C, Weinberg A N 1971 Mechanism of resistance to antibiotic synergism in enterococci. Journal of Bacteriology 105:873-879. 